\title{
PENERAPAN METODE PENEMUAN TERBIMBING PADA PEMBELAJARAN MATEMATIKA SISWA SMP
}

\author{
Agusman Riyadi $^{1}$, Dodik Mulyono², Lucy Asri Purwasi ${ }^{3}$ \\ STKIP-PGRI Lubuklinggau ${ }^{1,2,3}$ \\ Email. dodikmulyono@ stkippgri-lubuklinggau.ac.id ${ }^{2}$
}

\begin{abstract}
ABSTRAK
Penelitian ini bertujuan untuk mengetahui ketuntasan hasil belajar matematika Siswa Kelas VIII SMP Negeri 8 Lubuklinggau. Setelah diterapkan metode penemuan terbimbing. Metode penelitian yang digunakan dalam peneilitian ini adalah eksperimen semu dengan populasi kelas VIII 191 siswa dan sebagai sampel adalah kelas VIII F 32 siswa yang diambil secara acak.Pengumpul data yang dilakukan dengan teknik tes yang berupa soal essay.Data yang terkumpul dianalisis menggunakan uji-t. Berdasarkan hasil analisis data pada tarap kepercayaan $\alpha=0,05$ dapat disimpulkan bahwa hasil belajar siswa kelas VIII SMP Negeri 8 Lubuklinggau Tahun Ajaran 2016/2017 setelah rata-rata nilai tes akhir sebesar 81,27dan persentase jumlah siswa yang tuntas mencapai $82,14 \%$
\end{abstract}

Katakunci: Penemuan Terbimbing, Hasil Belajar, Matematika

\begin{abstract}
This study aims to determine the completeness of the results of learning mathematics Class VIII SMP Negeri 8 Lubuklinggau. Having applied guided discovery method. The research method used in this research is a quasi experiment with population class VIII 191 students and as a sample is class VIII F 32 students are taken at random. Data collecting is done by the test technique in the form of essay.Data problem is analyzed using t-test. Based on the results of data analysis on tarap belief $\alpha=0.05$ can be concluded that the results of students studying class VIII SMP Negeri 8 Lubuklinggau Academic Year 2016/2017 after the average value of the final test of 81.27 and the percentage of complete students reached $82.14 \%$
\end{abstract}

Keywords: Guided Discovery, Learning Outcomes, Mathematics 


\section{PENDAHULUAN}

Berdasarkan hasil studi pendahuluan di SMP Negeri 8 Lubuklinggau mengatakan bahwa metode pembelajaran yang digunakan dalam proses pembelajaran adalah metode konvesional. Ada beberapa masalah yang sering timbul di dalam menggunakan konvesional yaitu: 1) dalam proses belajar mengajar siswa kurang aktif dalam mengemukakan pendapatnya; 2) berkurangnya minat siswa terhadap pembelajaran matematika; 3) siswa cenderung pasif sehingga pemahaman siswa terhadap materi menjadi lambat karena siawa hanya menunggu informasi dari guru tanpa adanya usaha mencari informasi yang diperlukan dalam menyelesaikan masalah yang di hadapi; 4) kemandirian belajar siswa tergolong rendah.

Kemandirian belajar Kemandirian yang diartikan adalah tingkat kemandirian siswa dalam upaya memahami materi pembelajaran. Kemandirian belajar adalah mengembangkan proses pembelajaran siswa untuk menentukan tujuan, hal-hal dan pengalaman belajar, dan penilaian pembelajran (Mulyono, 2017). Penggunaan metode konvensional menyebabkan hasil belajar siswa kelas VIII masih tergolong rendah. Nilai rata-rata ulangan harian pada mata pelajaran matematika yang berjumlah 189 siswa, hanya 85 siswa atau 44,97\% siswa tuntas dan 104 siswa atau 55,03\% belum tuntas dan rata-rata ulanganharian yang diperoleh sebesar 60 .

Sehingga membuat sebagian besar siswa mengikuti remedial. Selain itu, beberapa siswa tidak bisa menjawab atau menyelesaikan soal yang sedikit berbeda yang dilakukan oleh guru dan siswa tidak berani untuk menanyakan tentang materi yang mereka anggap sulit atau belum dimengerti. Metode pembelajaran penemuan terbimbing adalah metode yang mengedepankan proses, siswa mampu menyesuaikan sesuatu konsep atau prinsip.

Metode pembelajaran penemuan terbimbing adalah proses mental dimana siswa mampu menyesuaikan sesuatu konsep atau prinsip. Proses pembelajaran meliputi mengamati pembelajaran, menggolong-golongkan, mengerti materi, mampu menjelaskan kembali materi yang di ajarkan, mampu membuat hipotesis, dapat menyimpulkan materi pembelajaran, dapat mengukur dan sebagainya. Teknik yang digunakan ini, siswa di fasilitasi dan diminta untuk dapat menemukan jawabannya sendiri atau siswa mengalami proses, peran guru dalam pembelajaran hanya menjadi fasilitator dan guru membimbing siswa jika diperlukan dan ada yang perlu dipertanyakan (Roestiyah, 2012).

Sedangkan menurut Hariyono, (2001) penemuan terbimbing merupakan kegiatan pembelaaran yang megedepankan pengalaman, metode ini tidak sepenuhnya pembelajaran diserahkan kepada peserta didik, namun guru berperan sebagai pembimbing dan fasilitator.

Siswa memiliki peran besar dalam kegiatan pembelajaran. Menurut Sani (2013) menyatakan bahwa metode penemuan terbimbing merupakan metode membangun konsep siswa namun dalam pengawasan dan bimbingan oleh guru. 
Suprihatiningrum, (2013), mengatakan bahwa metode pembelajaran penemuan adalah suatu metode yang mendorong peserta didik untuk selalu belajar lebih aktif, dengan cara melibatkan aktif dengan keiatan pembelajaran dengan konsepkonsep, dan guru memfasilitasi dan memotivasi siswa untuk mendapatkan pengalaman serta melakukan eksperimen yang tujuannya agar mereka dapat menemukan konsep dan prinsip untuk dirnya.

Menurut Suherman (2001), metode penemuan terbimbing adalah sebagai metode penemuan yang dilakukan oleh siswa. Berdasarkan beberapa pendapat ahli tersebut, dapat disimpulkan bahwa metode penemuan terbimbing adalah salah satu metode yang digunakan guru dalam proses pebelajaran yang berpusat kepada siswa, dimana di dalam proses ini siswa terlibat secara aktif untuk menemukan akan konsep-konsep dan prinsip- prinsip dengan menggunakan proses mentalnya sendiri sehingga siswa mendapatkan pengalaman belajar yang baru serta memahami apa tujuan dari pembelajaran.

\section{METODE PENELITIAN}

Metode penelitian yang digunakan adalah metode eksperimen semu (Quasi Eksperimen research). Adapun dalam penelitian eksperimen semu menurut Suryabrata (2010) adalah untuk memperoleh suatu informasi yang dalam keadaan tidak dimungkinkan untuk dikontrol dan dimanipulasi variabelnya. Jadi pada eksperimen semu, kegiatan penelitian dilakukan tanpa adanya kelas pembanding (kontrol).

\section{HASIL PENELITIAN DAN PEMBAHASAN}

Pelaksanaan penelitian dilaksanakan pada tanggal 13 Maret sampai dengan 13 April 2017 di kelas VIII SMP Negeri 8 Lubuklinggau. Pembelajaran matematika dengan Metode ini diajarkan pada siswa kelas VIII.F SMP Negeri 8 Lubuklinggau dengan uraian materi Kubus dan Balok. Sebelum pelaksanaan penelitian dimulai, terlebih dahulu dilakukan uji coba instrumen tes yang bertujuan mengetahui kualitas soal yang akan digunakan. Uji coba instrumen dilaksanakan di kelas IX SMP negeri 8 Lubuklinggau pada tanggal 13 maret 2017 dengan diikuti siswasebanyak 30 siswa pada materi luas permukaan dan volume pada kubus serta balok.

Dalam penelitian ini, peneliti mendapatkan data dengan menggunakan pemberian tes pre-test dan post-test, tes pre-test dan post-test tersebut diberikan kepada kelas yang menjadi sampel dalam pelaksanakan kegiatan pembelajaran dengan Metode Penemuan Terbimbing, pada materi Luas permukaan dan volume pada kubus serta balok.

Pre-test dilakukan untuk mengetahui kemampuan siswa sebelum diberikan pembelajaran matematika dengan diterapkan metode Penemuan terbimbing. Kemampuan siswa sebelum mengikuti pembelajaran materi Kubus dan Balok adalah merupakan data penelitian yang didapat dari tes awal atau soal yang 
diberikan sebelum siswa mendapatkan pembelajaran dari guru. Rekapitulasi analisis hasil Pre-test siswa dapat dilihat pada table 1

Tabel 1

Rekapitulasi hasil Pre-test

\begin{tabular}{lc}
\hline \multicolumn{1}{c}{ Kategori } & Hasil \\
\hline Rata-rata nilai & 21,83 \\
\hline Simpangan baku & 7.47 \\
\hline Nilai maksimum & 40 \\
\hline Nilai minimum & 11 \\
\hline Siswa yang tuntas & 0 orang $(0 \%)$ \\
\hline Siswa yang tidak tuntas & 30 orang $(100 \%)$ \\
\hline
\end{tabular}

Berdasarkan tabel 1 dapat dilihat bahwa siswa yang mendapat nilai lebih dari atau sama dengan KKM yang ditetapkan oleh sekolah yaitu 75 dalam Pre-test sebanyak 0 siswa (0\%) dan mendapat nilai kurang dari KKM adalah sebanyak 30 siswa $(100 \%)$.

Kemampuan akhir siswa dalam penugasan materi luas volume dan permukaan pada kubus serta balok merupakan hasil belejar setelah mengikuti proses pembelajaran matematiak dengan menggunakan metode Penemuan Terbimbing. Kemampuan akhir diperoleh melalui Post-test (tes akhir).Pelaksanaan Post-test berfungsi untuk mengetahui hasil belajar siswa setelah mengikuti kegiatan pembelajaran menggunakan metode penemuan terbimbing. Soal tes yang digunakan berbentuk essay yang terdiri dari 5 soal dengan jumlah skor adalah 47.rekapitulasinya dapat dilihat pada tabel 2 berikut:

Tabel 2

Rekapitulasi hasil Post-test

\begin{tabular}{lc}
\hline \multicolumn{1}{c}{ Kategori } & Hasil \\
\hline Rata-rata nilai & 81,27 \\
\hline Simpangan baku & 6,62 \\
\hline Nilai maksimum & 96 \\
\hline Nilai minimum & 68 \\
\hline Siswa yang tuntas & 25 orang $(83,3 \%)$ \\
\hline Siswa yang tidak tuntas & 5 orang $(16,7 \%)$ \\
\hline
\end{tabular}

Berdasarkan tabel 2 dapat dilihat bahwa siswa yang mendapat nilai lebih dari atau sama dengan KKM (75) dalam Post-test sebanyak 25siswa (83,3\%) dan nilai kurang dari KKM (belum tuntas) sebanyak 5 orang (16,7\%). Nilai yang tertinggi adalah 96 dan nilai yang terendah adalah 68. Rata-rata nilai secara keseluruhansebesar 81,27.

Jadi secara deskriptif dapat dikatakan bahwa kemampuan akhir siswa setelah pembelajaran dengan metode Penemuan Terbimbing dapat dikatakan 
tuntas, karena nilai rata-ratanya lebih dari KKM yaitu lebih dari 75 (>75). Untuk memperjelasnya dapat dilihat pada grafik dibawah ini:

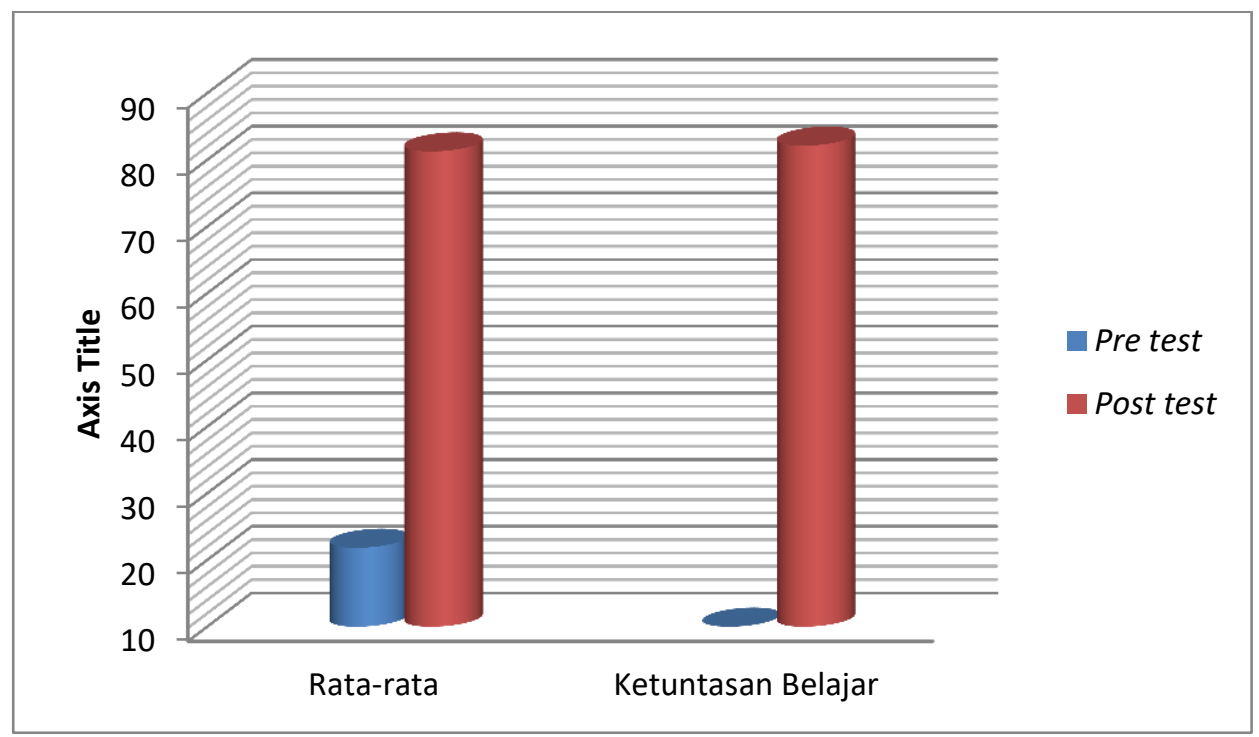

Grafik 1 Nilai Rata-rata dan Ketuntasan Belajar Pre-test dan Post-test

Pre-test dilaksanakan pada tanggal 27 Maret 2017, pembelajaran Pre-test Dilakukan untuk melihat dan mengukur kemampuan awal siswa sebelum diberikan perlakuan atau pelaksanaan pembelajaran yang diterapkan, apakah siswa dapat mengerjakan soal yang diberikan tersebut tuntas. Berdasarkan tabel 4.1 dapat dilihat bahwa 0 siswa yang mendapatkan nilai lebih dari 75 (tuntas). Nilai $(\bar{x})$ nilai siswa secara keseluruhan sebesar 21,83. Jadi dapat disimpulkan bahwa Pre-test sebelum diterapkan metode Penemuan Terbimbing adalah belum tuntas.

Setelah pemberian Pre-test pada kelas VIII SMP Negeri 8 Lubuklinggau, kemudian siswa diberikan perlakuan menggunakan metode Penemuan terbimbing sebanyak tiga kali pertemuan. Pelaksanakan pembelajaran dengan metode Penemuan Terbimbing dilakukan dengan cara guru menyampaikan tujuan pembelajaran yang ingin dicapai, kemudian guru menjelaskan materi yang berkenaan dengan materi pelajaran, kemudian guru membagi dan terbentukalah 5 kelompok dan setiap kelompok terdiri dari 6 orang siswa yang heterogen. Setelah kelompok terbentuk kemudian membagikan Lembar Kerja Siswa (LKS) yang harus diselesaikan oleh siswa. Setiap siswa berdiskusi dengan teman satu kelompoknya untuk merumuskan masalah dan menganalisis data sesuai petunjuk pada LKS, Kemudian siswa, mempresentasikan hasil diskusi kelompoknya.

Pada pertemuan pertama dilaksanakan pada tanggal 30 Maret 2017, setelah peneliti menjelaskan proses pembelajaran dengan menggunakan metode pembelajaran Penemuan Terbimbing, menyampaikan tujuan pembelajaran dan menjelaskan materi yang berkenaan dengan materi pelajaran, dan membagi 
kelompok, peneliti membagi Lembar Kerja Siswa (LKS) mengenai materi Luas permukaan dan volume pada kubus serta balokdengan indikator yang harus dicapai siswa adalah Memahami rumus dan menghitung luas permukaan kubus dan balok. Saat siswa berdiskusi untuk menemukan Luas permukaan dan volume pada kubus serta balok siswa mengalami kesulitan..

Adapun kesulitan yang dialami siswa antara lain siswa belum terbiasa mengikuti pembelajaran dengan menggunakan Penemuan Terbimbing karenacara mengajar yang digunakan adalah hal yang baru bagi siswa sehingga siswa memerlukan pemahaman terhadap metode pembelajaran yang digunakan dan setelah siswa mendapatkan LKS, siswa banyak yang bertanya karena mereka masih bingung dengan permasalahan yang ada dalam LKS.

Selain itu siswa juga mengalami kesulitan dalam melakukan penemuan konsep dari suatu materi yang sedang mereka pelajari, hal ini disebabkan karena siswa terbiasa menerima materi pelajaran yang diberikan oleh guru. Adapun hambatan yang lain siswa kurang berani dalam mempresentasikan hasil penemuannya di depan kelas sehingga dalam menyampaikan hasil penemuannya kurang maksimal karena terdengar kurang jelas oleh siswa lain.

Dengan demikian peneliti memberi pengarahan dan bimbingan supaya siswa lebih berani dalam mengemukakan pendapatnya.Dari hasil diskusi, kemudian dengan bimbingan peneliti, siswa menyimpulkan kegiatan diskusi.Pada pertemuan pertama kelompok yang mampu menyelesaikan masalah dengan baik sebanyak tiga kelompok, sedangkan dua kelompok lagi masih banyak kesalahan.

Pada pertemuan kedua siswa sudah mulai memahami metode pembelajaran Penemuan Terbimbing setelah LKS II dibagikan mereka sudah tahu apa yang harus dilakukannya. Sehingga mereka langsung menyelidiki dan menemukan permasalahan yang ada dalam LKS.Tetapi sebagian dari mereka ada yang masih bingung dan mengalami kesulitan karena mungkin lupa dengan pelajaran yang sudah dipelajari sebelumnya.

Dengan demikian peneliti memberikan arahan kepada siswa yang belum mengerti.Setelah hasil diskusi mereka selesai, mereka mempresentasikan didepan kelas. Setelah itu membuat kesimpulan.Kelompok yang mampu menyelesaikan masalah pada pertemuan kedua sebanyak dua kelompok, sedangkan kelompok lain juga sudah mampu menyelesaikan masalah namun belum mampu memberikan penjelasan yang sesuai dan masih terdapat kesalahan.

Pada pertemuan ketiga, tidak ada siswa yang mengalami kesulitan karena mereka sudah paham dengan permasalahan yang ada pada LKS yang diberikan, dan semua siswa telah mencapai hasil yang baik karena sudah memahami materi yang telah diberikan sebelumnya, sehingga peran peneliti hanya mengecek dan mengawasi.Pada pertemuan ketiga lima kelompok sudah mampu menyelesaikan masalah dengan baik, sedangkan satu kelompok lagi masih terdapat kesalahan.

Selanjutnya satu kelas diberikan tes akhir (post-test)sebagai tolak ukur keberhasilanpembelajaran yang dilakukan. Tes akhir dilaksanakan pada tanggal 
10 April 2017, Berdasarkan hasil post-test pada kelas eksperimen diperoleh nilai rata-rata siswa $(\bar{x})$ adalah 81,27 . Berdasarkan hasil nilai rata-rata kelas eksperimen ternyata nilai rata-rata kelas eksperimen lebih tinggi. Hal ini disebabkan karena kelas eksperimen menggunakan metode pembelajaran Penemuan Terbimbing .

Kendala dalam menggunakan metode Penemuan Terbimbing yaitu sebagian dari siswa belum mampu melakukan penemuaan. Akan tetapi kendala dalam peneliti ini dapat atasi dengan cara pembentukan kelompok belajar dengan teman sebangkunya masing-masing. Adapun kesulitan lain selama proses pembelajaran dengan menggunakan metode Penemuan Terbimbing yaitu ada sebagian siswa yang tidak mengikuti kegiatan pada saat berdiskusi.

Siswa terkadang ribut dan suasana kelas menjadi ramai, sehingga alokasi waktu yang digunakan untuk membahas hasil diskusi terpotong untuk menenangkan kelas. Namun, peneliti mampu mengatasi kendala tersebut dengan cara harus membatasi waktu siswa dalam berdiskusi. Peneliti menegur siswa yang tidak aktif dan tidak menyimak penjelasan guru atau tidak bekerja sama dalam teman sebangkunya. Selain itu mengarahkan dan mendorong siswa dalam menentukan jawaban sementara, pengumpulan data dan penyelesaian masalah.Peneliti harus mengelola pembelajaran mulai dari memanfaatkan waktu pembelajaran dengan efektif agar seluruh kegiatan pembelajaran dapat terlaksana dengan baik.

Dengan diterapkannya metode penemuan terbimbing dalam kegiatan pembelajaran ini siswa mulai merasa senang belajar matematika dikarenakan siswa dengan leluasa bisa mengeluarkan pendapatnya untuk menyelidiki suatu permasalahan, mendorong keaktifan siswa untuk berpikir dan menemukan hasil akhir dari permasalahan yang diberikan, baik itu berupa pertanyaan yang berisi tentang ketidakpahaman siswa tentang materi luas permukaan dan volume pada kubus serta balokataupun jawaban yang melatih siswa berani mangeluarkan pendapatnya dan menumbuhkan rasa percaya diri siswa terhadap kemampuannya sendiri.

Hasil penelitian ini sejalan dengan pendapat Suprihatiningrum, (2013), metode pembelajaran penemuan adalah suatu metode pembelajaran yang dapat mendorong peserta didik untuk belajar aktif dan guru sebagai fasilitator memibimbing siswa untuk mendapatkan pengalaman yang nantinya akan mendapatkan atau menemukan konsep sendiri.

Setelah dilakukan uji hipotesis dengan uji-t menghasilkan bahwa $t_{\text {hitung }}>t_{\text {tabel }}$ dengan nilai 5,18 $>1,69$ ini membuktikan bahwa hipotesis dalam penelitian ini diterima dan $\mathrm{H}_{0}$ ditolak yaitu rata-rata hasil belajar matematika yang menggunakan metode penemua terbimbinglebih dari rata-rata hasil belajar matematika siswa.Sehingga dapat disimpulkan bahwa hipotesis dalam penelitian ini diterima, yaitu ada penerapan metode penemuan terbimbing pada pembelajaran matematika siswa kelas VIII SMP Negeri 8 Lubuklinggau. 


\section{SIMPULAN}

Berdasarkan hasil penelitian, maka dapat disimpulkan bahwa hasil belajar matematika siswa kelas VIII SMP Negeri 8 Lubuklinggau setelah penerapan metode penemuan terbimbing secara signifikan tuntas". Hal ini dibuktikan dari hasil analisis uji-t pada taraf signifikan $\alpha=0,05$ diperoleh $t_{\text {hitung }}(5,18)>t_{\text {tabel }}$ $(1,69)$, yang berarti Ho ditolak dan Ha diterima. Rata-rata nilai akhir siswa sebesar 81,27 .

\section{DAFTAR PUSTAKA}

Hariyono, (2001). Dasar-dasar akuntasi jilid 2. STIE YKPN.

Mulyono, Dodik. (2017). The Influence Of Learning Model And Learning Independence On Mathematics Learning Outcomes By Controlling Students' Early Ability. Lubuklinggau : Look Academic Publishes Open Acces

Roestiyah. (2012). Strategi Belajar Mengajar. Jakarta: Rineka Cipta

Sani, R. A. (2013). Pembelajaran Saintifik untuk Implementasi Kurikulum 2013. Jakarta: PT Bumi Aksara.

Suherman, E, (2001). Common Text Book Strategi Pembelajaran Matematika Kontemporer. Bandung: JICA-Universitas Pendidikan Indonesia (UPI).

Suprihatiningrum, Jamil. (2013). Strategi Pembelajaran: Teori \& Aplikasi. Jogjakarta: Ar-Rus Media.

Suryabrata, (2010). Resume Metodologi Penelitian, Jakarta: rajawali pers. 